\title{
ANALISIS KARAKTERISTIK PASAR SENIOR LIVING D'KHAYANGAN JABABEKA, CIKARANG
}

\author{
Bertharia Nadya Pricillia ${ }^{1)}$, Priyendiswara A.B. ${ }^{2)}$, Liong Ju Tjung ${ }^{3)}$
}

1)Program Studi S1 PWK, Fakultas Teknik, Universitas Tarumanagara, nadya.bertharia97@gmail.com

2)Program Studi S1 PWK, Fakultas Teknik, Universitas Tarumanagara, priyendiswaraa@ft.untar.ac.id

${ }^{3)}$ Program Studi S1 PWK, Fakultas Teknik, Universitas Tarumanagara, jt.liong@pps.untar.ac.id

\begin{abstract}
Abstrak
Jumlah lansia di Indonesia, berdasarkan data Badan Pusat Statistik (BPS) tahun 2017 telah mencapai 23,4 juta atau 8,97\%. Dengan berbagai data yang menunjukkan tingkat lansia yang tinggi di Indonesia, hunian yang mendukung kenyamanan, keamanan dan kesehatan para lansia sangat dibutuhkan. Hunian lansia di Jabodetabek pada kenyataannya sudah tersedia namun belum memenuhi permintaan yang ada. Maksud dan tujuan studi ini adalah melakukan analisis karakteristik pasar yang terdiri dari profil lansia yang berminat tinggal di rumah lansia, kemampuan pasar, pasokan rumah lansia yang tersedia, jumlah permintaan rumah lansia, dan penentuan harga sewa yang tepat. Adapun objek studi yang diteliti yaitu Senior Living D'Khayangan Jababeka yang berlokasi di Cikarang, Kabupaten Bekasi. Metode penelitian yang digunakan dalam pengumpulan data yaitu survey lapangan, penyebaran kuesioner dan wawancara terhadap pihak terkait. Analisis yang dipakai ialah analisis objek studi pembanding (benchmarking) dan pasar. Output dari analisis ini adalah penentuan harga sewa yang sesuai karakteristik pasar dari rumah lansia dan dapat menjadi properti berbasis sosial yang layak dalam segi pasar.
\end{abstract}

Kata Kunci: Analisis Pasar; Komunitas Pensiunan; Lansia; Rumah Lansia; Senior Living

\begin{abstract}
The number of elderly people in Indonesia, based on data from the Central Statistics Agency (BPS) in 2017 has reached 23.4 million or $8.97 \%$. With a variety of data that shows a high level of elderly people in Indonesia, housing that supports the comfort, safety and health of the elderly is quite needed. The occupancy of the elderly in Jabodetabek is in fact already available but has not filled the demand. The purpose and objective of this study is to analyze market characteristics which consist of profiles of elderly people who are interested in living in senior housing, market capabilities, available supply ofsenior housing, number of requests forsenior housing, and determination of appropriate rental prices. The object study is Senior Living D'Khayangan Jababeka which located in Cikarang, Bekasi Regency. The research method used in data collection is field surveys, questionnaires and interviews with related parties. The analysis used is the analysis of the object of benchmarking and market. The output of this analysis is the determination of rental prices that match the market characteristics of senior housing and can be viable social-based properties in terms of markets.
\end{abstract}

Keywords: Elderly; Market Analysis; Retirement Community; Senior Housing; Senior Living

\section{PENDAhUluan}

Jumlah lansia di Indonesia, berdasarkan data Badan Pusat Statistik (BPS) tahun 2017 telah mencapai 23,4 juta atau 8,97\%. Dalam persentasenya lansia di umur 60-69 menduduki persentase tertinggi yaitu $5,6 \%$ laki-laki dan $5,71 \%$ perempuan. Jika dibandingkan dengan lansia umur 70-79 dan 80+ yang hanya 1-2\% persentasenya. Sedangkan menurut Joseph Kandel dan Christine Adamec dalam buku The Encyclopedia of Senior Health and Well-Being (2013), pertumbuhan lansia Indonesia dari survey yang dilakukan tahun 1900 oleh U.S. Census Bureau tahun 2000 sampai tahun 2030 masuk dalam peringkat ke 6 mencapai $240 \%$ yang setara dengan Filipina. Dengan berbagai data yang menunjukkan tingkat lansia yang tinggi di Indonesia, hunian yang mendukung kenyamanan, keamanan dan kesehatan para lansia dibutuhkan. Hunian para 
lansia khususnya di Jabodetabek, ditunjang dengan adanya panti jompo atau senior living. Namun, hal tersebut masih menjadi hal yang tidak wajar untuk merelokasikan para lansia ke panti jompo. Berbeda dengan panti jompo pada umumnya yang semata hanya menjadi tempat lansia menghuni dan berkumpul namun menjalin hubungan yang lebih erat dan harapan hidup yang lebih tinggi. Senior Living D'Khayangan Jababeka, Cikarang dapat mendukung kebutuhan para lansia tersebut. Namun dari kondisi eksisting, penghuni masih sedikit. Dari lahan seluas 5,2 Ha terdapat lahan sisa sebanyak 4,1 Ha untuk dikembangkan untuk dilakukan studi pasar dari benchmarking dari senior housing lain agar dapat sesuai dengan market segmentation yang sesuai dengan pasar.

\section{KAJIAN LITERATUR}

Lanjut usia atau yang sering disebut lansia (elderly) menurut World Health Organization (WHO), merupakan orang yang berusia antara 60 sampai dengan 74 tahun. Sedangkan lanjut usia tua (old) merupakan orang yang berusia antara 75 sampai dengan 90 tahun dan usia sangat tua (very old) untuk orang yang berusia diatas 90 tahun. Di Indonesia memiliki standar lanjut usia yang berbeda, menurut UU No.4 tahun 1965 Pasal 1:

"Seorang dapat dinyatakan sebagai seorang jompo atau lanjut usia setelah yang bersangkutan mencapai umur 55 tahun, tidak mempunyai atau tidak berdaya mencari nafkah sendiri untuk keperluan hidupnya sehari-hari dan menerima nafkah dari orang lain".

Dalam menentukan market area, Maxfield Reaserch inc. Dalam laporan A Market Feasibility Study for an Independernt Senior Rental Development in Lexington, Minnesota (2010), menentukan catchment area untuk perumahan senior berdasarkan arus lalu lintas dan pola orientasi masyarakat setempat, batasan geografis dan batas administrasi serta lokasi perumahan senior yang kompetitif berdasarkan karakteristik pengembangan subjek. Market area primer yang ditetapkan akan memberikan $80 \%$ dari total market untuk pengembangan senior housing. Porsi supply yang tersisa akan berasal dari luar market area primer yang ditentukan. Bagian permintaan ini akan terdiri dari orang-orang yang saat ini tinggal tepat di luar market area primer yang memiliki orientasi ke daerah (gereja, dokter) orang-orang yang pernah tinggal di daerah tersebut dan keinginan untuk kembali dan orang tua dari orang-orang usia produktif yang tinggal di market area primer.

Lansia juga mempunyai kebutuhan hidup seperti orang lain agar kesejahteraan hidup dapat dipertahankan. Kebutuhan hidup seperti kebutuhan makanan yang mengandung gizi seimbang, pemeriksaan kesehatan secara rutin dan sebagainya diperlukan oleh lansia agar dapat mandiri. Menurut pendapat Maslow dalam teori Hierarki Kebutuhan, kebutuhan manusia meliputi:

a. Kebutuhan fisik (physiological needs) adalah kebutuhan fisik atau biologis seperti pangan, sandang, papan, seks dan sebagainya.

b. Kebutuhan ketentraman (safety needs) adalah kebutuhan akan rasa keamanan dan ketentraman, baik lahiriah maupun batiniah seperti kebutuhan akan jaminan hari tua, kebebasan kemandirian dan sebagainya.

c. Kebutuhan sosial (social needs) adalah kebutuhan untuk bermasyarakat atau berkomunikasi dengan manusia lain melalui paguyuban,organisasi profesi, kesenian, olah raga, kesamaan hobi dan sebagainya.

d. Kebutuhan harga diri (esteem needs) adalah kebutuhan akan harga diri untuk diakui akan keberadaannya.

e. Kebutuhan aktualisasi diri (self actualization needs) adalah kebutuhan untuk mengungkapkan kemampuan fisik, rohani maupun daya pikir berdasar pengalamannya masing-masing, bersemangat untuk hidup dan berperan dalam kehidupan. 


\section{METODE}

Jenis penelitian ini adalah kualitatif dan kuantitatif.

Penelitian ini terdapat dua jenis data yaitu data primer dan data sekunder, antara lain sebagai berikut.

a. Data Primer

Data primer merupakan data yang di dapat langsung dari objek penelitian. Pengumpulan data primer yaitu sebagai berikut:

1. Kondisi fisik eksisting Senior Living D'Khayangan Jababeka dan 3 panti sebagai benchmark

2. Wawancara kepada pihak pengelola Senior Living D'Khayangan Jababeka

3. Penyebaran kuesioner kepada penghuni panti/Senior Living pembanding

b. Data Sekunder

Data sekunder merupakan data yang didapatkan dari berbagai sember yang relevan seperti buku, jurnal, market overview dan internet yang dapat dipertanggungjawabkan. Data sekunder yang diperoleh adalah sebagai berikut:

1. Benchmarking

2. Sejarah dan dokumentasi Senior Living D'Khayangan Jababeka

3. Data lokasi dan fasilitas Senior Living D'Khayangan Jababeka

4. Jenis-jenis Senior Housing

5. Site Plan Senior Living D'Khayangan Jababeka

Untuk melakukan pengumpulan data dilakukan agar mendapatkan data mengenai objek studi. Dalam hal ini adalah Senior Living D'Khayangan Jababeka, maka dari itu diperlukan metode pengumpulan data yang sesuai dengan kebutuhan. Maka diperlukan teknik pengumpulan data sebagai berikut.

Teknik Pengumpulan Data Primer

a. Survey Lapangan

Survey lapangan merupakan metode pengamatan langsung yang dilakukan oleh Penulis dan tidak bisa didapatkan melalui cara sekunder. Survey lapangan memiliki tujuan untuk mengetahui kondisi eksisting dari objek yang akan diteliti.

b. Wawancara

Wawancara dilakukan dengan pihak terkait yaitu divisi Masterplan Jababeka dan pengelola dari Senior Living D'Khayangan Jababeka.

c. Kuesioner

Kuesioner dibuat dan disebarkan untuk mengetahui karakteristik lansia seperti apa yang tinggal di dalam persepsi penghuni yang merupakan lansia yang ada di Senior Living D'Khayangan Jababeka dan di 5 senior housing lainnya yang merupakan best practice untuk mengetahui faktor pemilihan Senior Living tersebut dan kuesioner yang disebar untuk mengetahui demand pasar senior housing dengan membagikan kuesioner kepada lansia berusia 60 keatas di Jabodetabek.

\section{DISKUSI DAN HASIL}

Lokasi Senior Living D'Khayangan, Jababeka terletak di Cikarang Timur, Kabupaten Bekasi, Jawa Barat. Lokasi saat ini merupakan Senior Living D'Khayangan, Jababeka merupakan panti werdha kelas atas yang di kelola oleh PT. Jababeka di kawasan seluas 5,24 Ha. 

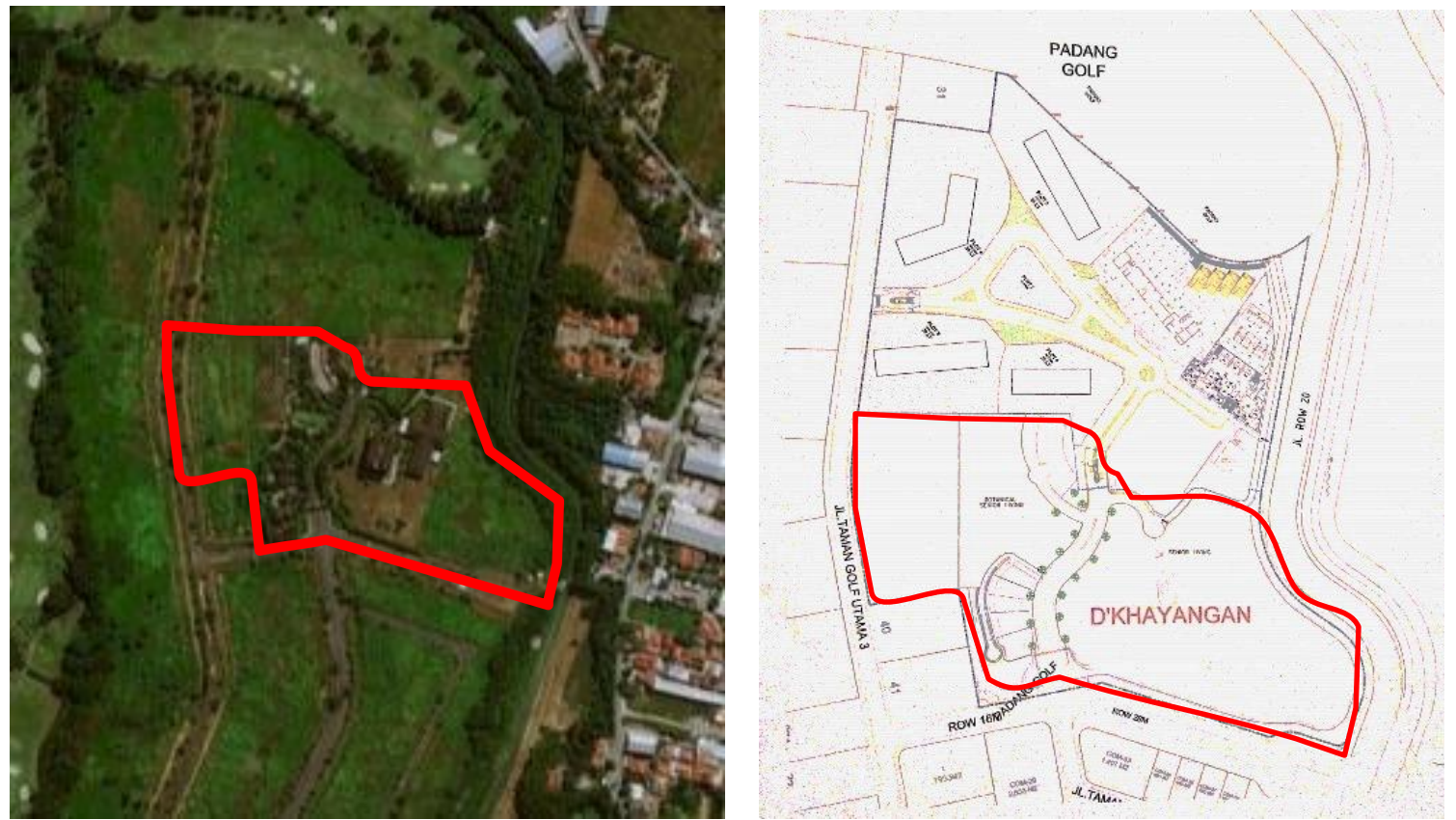

Gambar 1. Site Plan Kawasan Senior Living D'Khayangan Jababeka Sumber: PT. Jababeka, Tbk, 2019

Lokasi objek studi terletak di bagian timur kota DKI Jakarta. Lokasi objek studi juga terletak tepat $\pm 35 \mathrm{~km}$ diatara Kota Bekasi dan Kota Karawang. Aksesibilitas baik menuju maupun dari lokasi objek studi dapat dapat dicapai melalui jalan tol Jakarta-Cikampek atau bangkitan lebih banyak dari arah barat objek studi. Hasil analisis menunjukkan bahwa aksesibilitas mikro dari objek studi dapat dicapai melalui Jalan Tol Jakarta-Cikampek dengan 3 pintu keluar tol yaitu Cikarang Utama pada KM 29, Cikarang Barat pada KM 31, dan Cibatu pada KM 34,7.
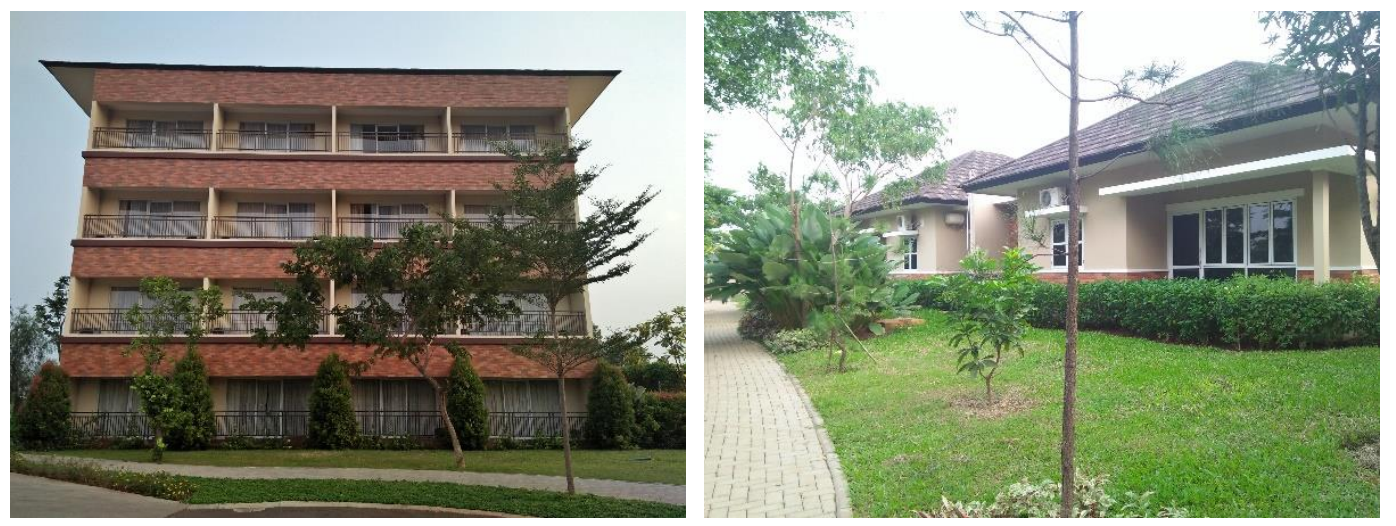

Gambar 2. Kondisi Kawasan Senior Living D'Khayangan Jababeka Sumber: Penulis, 2019

Lokasi objek studi terdapat pada Kawasan Industri Jababeka yang memiliki produk properti residential dalam kawasannya yaitu Jababeka Residence. Dari lokasi sekitar objek studi, residensial ini merupakan sarana kalangan umum untuk bermukim dan menjadi tempat bagi anak dari lansia yang menghuni senior living. Walaupun senior living ini terletak pada lingkungan perindustrian, tepatnya di Kawasan Jababeka 2, kawasan senior living ini memiliki buffer atau penyangga polusi berupa penghijauan di sekitarnya. Lokasi objek studi berada pada kawasan Jababeka 2 yang meliputi residensial, komersial, industri dan fasilitas. Industri yang terdapat di sekitar lokasi objek studi merupakan industri ringan/light industry seperti packaging (PT. AIDA), warehouse (Tupperware), dan pabrik manufaktur (Mattel Indonesia). 
Selain itu, lingkungan sekitar dari Kabupaten Bekasi sendiri dekat dengan kawasan pemakaman kelas atas yang berlokasi di Karawang.Terdapat penyebaran kawasan pemakaman kelas atas sebanyak 4 kawasan yang berlokasi di Karawang. Diantaranya yaitu San Diego Hills Memorial Parks, Al Azhar Memorial Garden, Graha Sentosa Memorial Park dan Lestari Memorial Park.

Rumah lansia yang ada di Indonesia belum menerapkan konsep senior living atau berbasis komunitas dan entertain. Konsep yang terkandung dalam rumah lansia masih menjadi "rumah penampungan lansia" yang dimana lansia tersebut telah ditinggalkan oleh kerabat dan saudaranya. Walaupun masih tetap ada rumah lansia dengan konsep komunitas dan entertain dengan biaya yang dikenakan, hal ini tetap tertutupi oleh lebih banyaknya rumah lansia yang disubsidi oleh pemerintah dengan karakter penghuni adalah lansia terlantar. Dalam trendnya, para warga lansia di Indonesia yang menerima pensiun kurang dari $20 \%$. Para lansia laki-laki yang masih harus bekerja adalah sebesar $80 \%$, perempuan $20 \%$. Yang bekerja di sektor pertanian $48,51 \%$, sementara yang tidak lulus SD atau tidak sekolah mencapai $65,7 \%$. Dukungan keluarga juga masih sangat besar. Para lansia yang masih tinggal dengan keluarga mencapai 75,38\%. Yang tinggal dengan orang lain atau tinggal sendiri juga masih cukup banyak, 24,62\%. Adapun yang telantar tercatat sekitar $15 \%$ atau sekitar 2,7 juta jiwa dari populasi Indonesia. Sedangkan dari sisi ekonomi lansia, pendapatan yang diterima sebagian besar dari pensiunan, anak dan hasil usaha.

Pensiunan yang diterima berdasarkan hasil survey ke salah satu panti jompo di Jakarta yaitu dengan range $\mathrm{Rp} 2.500 .000$ - Rp 5.500.000 per bulannya. Berdasarkan data dari salah satu cabang Bank BNI, investasi lansia di bank adalah mayoritas < Rp 100.000.000. Hal ini beralasan karena lansia tidak membutuhkan uang yang banyak untuk biaya hidup sehari-hari dan lebih banyak berinvestasi langsung kepada aset tetap serta diberikan ke anak. Sedangkan menurut data dari salah satu cabang Bank UOB, investasi lansia mayoritas di dalam range Rp 100.000.000 - Rp 500.000.000. Alasan yang ditemukan juga karena investasi kepada aset tetap seperti properti maupun tanah.

Setelah mengetahui profil dari lokasi objek studi dan trend senior housing, dilakukanlah analisis benchmarking atau studi pembanding kepada 3 rumah lansia yang memenuhi karakteristik yaitu bersegmentasi pada lansia dengan profil menengah keatas. Analisis ini bertujuan untuk mengetahui kunci kesuksesan dari senior housing dengan kelas menengah keatas lainnya yaitu Panti Werdha AUSSI Kusuma Lestari, Panti Werdha Hana, dan Sasana Tresna Werdha RIA Pembangunan. Di Indonesia, konsep senior housing dengan sebutan 'Senior Living' belum familliar dan eksklusif sehingga penghuninya masih sedikit. Sedangkan sebutan yang digunakan adalah 'Panti Werdha' dan 'Sasana Tresna Werdha'.

Berikut adalah hasil dari wawancara dengan 60 penghuni di 3 rumah lansia pembanding. Dari aspek-aspek yang mempengaruhi, berikut adalah hasil karakteristik lansia dari senior housing yang dijadikan pembanding:

- Lansia yang tinggal adalah mayoritas memilih tipe kamar yang standar dengan ketercukupan fasilitas yang disediakan

- Lansia yang tinggal merupakan lansia yang berdomisili di Jabodetabek

- Lansia yang tinggal mayoritas merupakan lansia dengan kondisi telah ditinggalkan oleh pasangan maupun tidak menikah

- Alasan lansia tinggal mayoritas karena tidak ingin merepotkan anak maupun karena sudah tidak ada kerabat/saudara

- Sumber penghasilan lansia yang tinggal rata-rata didapatkan dari gaji pensiun dan pemberian anak

- Kegiatan favorit para lansia cenderung menyukai kegiatan fisik seperti olahraga dengan tema yang menyangkut kesehatan

- Alasan pemilihan lokasi senior housing mayoritas karena rekomendasi kerabat maupun teman 
- Lansia lebih mengutamakan fasilitas yang lengkap (klinik, dokter jaga, fasilitas kamar, taman, dII)

- Lansia tidak bermasalah dengan menu makanan yang disediakan, selama diberikan secara rutin dan porsi yang cukup

Setelah mengetahui karakter lansia yang tinggal di senior housing, dilakukanlah penyebaran 100 kuesioner menurut rumus Slovin dan metode random sampling, dengan ketentuan lansia sebagai berikut:

A. Lansia berusia 60 tahun keatas

B. Lansia yang berdomisili di Jabodetabek

C. Lansia yang memiliki penghasilan/pendapatan baik dari simpanan, pensiunan maupun pemberian anak $\leq$ Rp 5.000.000

D. Lansia yang masih mandiri

Berikut adalah hasil dari penyebaran kuesioner kepada lansia yang bertujuan untuk mengetahui minat lansia terhadap senior housing:

Tabel 1. Crosstab Penghasilan per Bulan x Minat Terhadap Senior Housing

\begin{tabular}{|c|c|c|c|}
\hline & & Penghasilan per & \\
\hline & & Bulan & Total \\
\hline & & $>\operatorname{Rp} 5.000 .000$ & \\
\hline \multirow{5}{*}{$\begin{array}{l}\text { Minat untuk Tinggal di } \\
\text { Senior Housing }\end{array}$} & Sangat Tidak Tertarik & 18 & 18 \\
\hline & Tidak Tertarik & 15 & 15 \\
\hline & Ragu-Ragu & 29 & 29 \\
\hline & Tertarik & 21 & 21 \\
\hline & Sangat Tertarik & 17 & 17 \\
\hline \multicolumn{2}{|c|}{ Total } & 100 & 100 \\
\hline
\end{tabular}

Sumber: Penulis, 2019

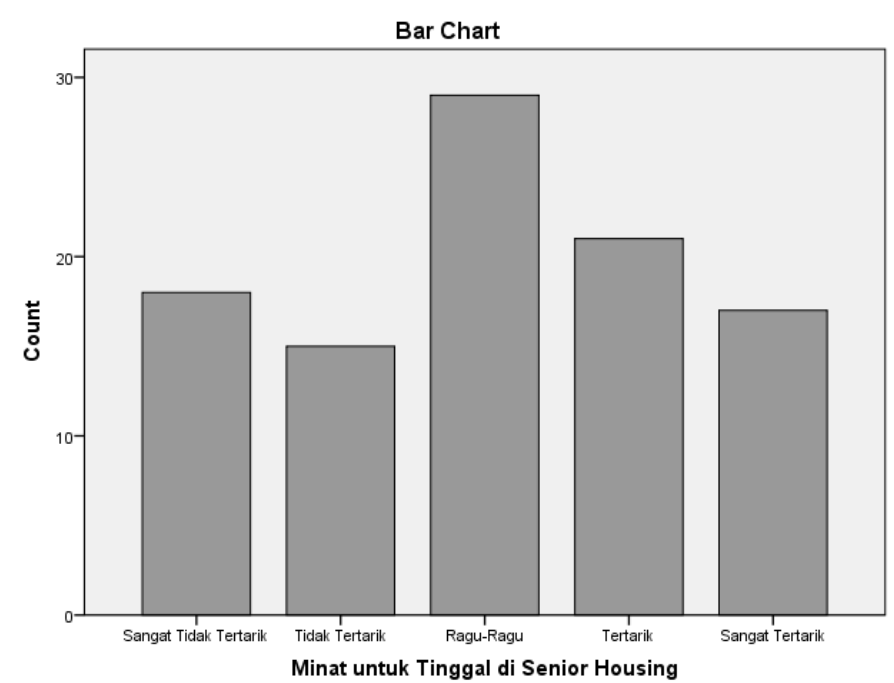

Gambar 2. Minat untuk Tinggal di Senior Housing

Sumber: Penulis, 2019

Market area yang menjadi terget objek studi adalah Jakarta, Bogor, Depok, Tangerang dan Bekasi (Jabodetabek). Jumlah penduduk Jabodetabek adalah 26.854.716 jiwa dengan luas Jabodetabek yaitu $6.938,9 \mathrm{~km}^{2}$.

- Diasumsikan:

Berminat = Sangat Tertarik, Tertarik, Ragu-Ragu (skor 3,4,5)

Tidak Berminat $=$ Sangat Tidak Tertarik dan Tidak Tertarik $($ skor 1,2) 
- Hasil persentase yang di dapatkan:

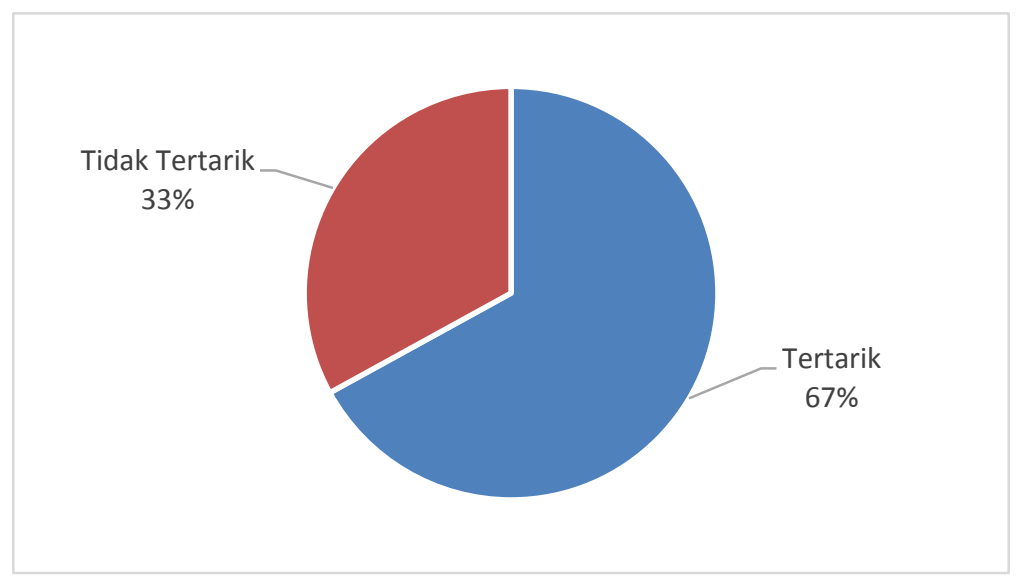

Gambar 3. Hasil Persentase Perminatan Lansia Terhadap Senior Housing Sumber: Penulis, 2019

Dari asumsi yang dilakukan, $67 \%$ responden yang mewakili lansia se-Jabodetabek menjadi acuan untuk mengetahui target pasar dari senior housing adalah:

Target Pasar $=$ (Jumlah Lansia di Jabodetabek $\mathrm{x}$ Persentasi kelompok lansia pengeluaran teratas) $x$ Persentase Demand Senior Housing

$$
\begin{aligned}
& =(1.925 .896 \times 18,65 \%) \times 67 \% \\
& =359.179,604 \times 67 \% \\
& =240.650,33468 \approx 240.651 \text { jiwa }
\end{aligned}
$$

Dari 21 rumah lansia yang ada di Jabodetabek, terdapat 5 senior housing dengan syarat dibangun oleh swasta (non-subsidi) dengan kelas menengah keatas (middle-up), fasilitas yang sepadan dan tipe bangunan apartemen/high-rise yang menjadi kompetitor yaitu Panti Werdha Hana, Sasana Werdha Tresna RIA Pembangunan, Graha Werdha AUSSI Kusuma Lestari, Senior Living \& Resort Beth Theresia dan Rukun Senior Living. Berikut adalah kriteria penilaian dari rumah lansia yang menjadi kompetitor. Berikut adalah peta lokasi 5 kompetitor yang ditunjukkan dengan legenda nomor berwarna kuning tersebut:

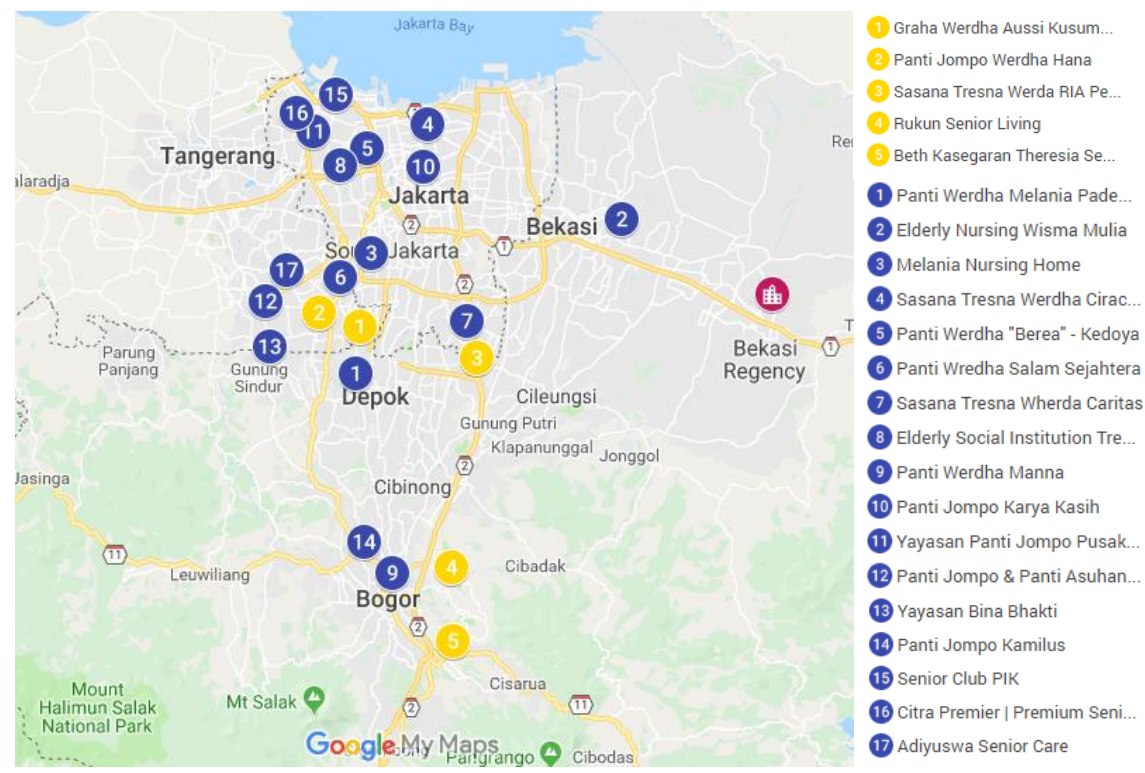

Gambar 4. Persebaran Lokasi Kompetitor (legenda berwarna kuning) Sumber: Penulis, 2019 
Dari hasil penyebaran kuesioner kepada lansia di Jabodetabek, diperoleh alasan-alasan dari indikator tertarik $(3,4,5)$ dan tidak tertarik $(1,2)$. Berikut adalah hasil dari penyebaran kuesioner:

A. Tertarik:

1) Ingin mencoba pergaulan dengan teman sebaya

2) Tidak ingin merepotkan anak

3) Mencari kegiatan

4) Tidak memiliki anak

5) Terlihat menyenangkan dan seru

6) Bosan di rumah

B. Tidak tertarik:

1) Tidak diizinkan anak

2) Nyaman dengan rumah pribadi

3) Nyaman dengan keluarga sendiri

4) Memiliki usaha

5) Masih bekerja (profesional)

6) Tidak ingin membatasi interaksi masyarakat

7) Tidak mengenal kondisi senior housing

8) Bisa merawat diri sendiri

Lansia memiliki alasan masing-masing yang mengindikasikan tertarik maupun tidak tertariknya terhadap senior housing. Namun mayoritas alasan tertarik dan ketidak tertarikan bergantung pada kondisi fisik maupun kondisi keluarga yang ada. Seperti beberapa responden yang kondisinya masih aktif bekerja, maupun nyaman di rumah karena masih berkeluarga (serumah dengan istri/suami dan anak). Sedangkan responden yang tertarik cenderung terpaut kondisi keluarga yang sudah terpisah dengan anak maupun telah ditinggalkan pasangan dan tidak memiliki kegiatan harian. Jadi dalam ketertarikan lansia terhadap senior housing bukan karena kondisi ekonomi namun dipicu oleh faktor kondisi keluarga, fisik dan tingkat kesibukan lansia.

Tabel 2. Hasil Perhitungan Market Positioning

\begin{tabular}{|c|c|c|c|c|c|c|c|}
\hline \multirow{2}{*}{ No } & \multirow{2}{*}{ Kompetitor } & \multirow{2}{*}{ Score } & \multirow{2}{*}{ Competitive } & \multirow{2}{*}{$\begin{array}{c}\text { Market } \\
\text { Share }\end{array}$} & \multicolumn{3}{|c|}{ Harga Sewa/kamar/bulan } \\
\hline & & & & & Lower & Middle & Upper \\
\hline & Panti Werdha & & & & & & \\
\hline 1 & $\begin{array}{l}\text { AUSSI Kusuma } \\
\text { Lestari }\end{array}$ & 78,4 & $78 \%$ & $17 \%$ & Rp4.500.000 & Rp9.000.000 & Rp20.000.000 \\
\hline 2 & $\begin{array}{l}\text { Panti Werdha } \\
\text { Hana }\end{array}$ & 72,6 & $73 \%$ & $16 \%$ & Rp8.000.000 & Rp20.000.000 & Rp23.900.000 \\
\hline 3 & $\begin{array}{l}\text { Sasana Tresna } \\
\text { Werdha RIA } \\
\text { Pembangunan }\end{array}$ & 83,4 & $83 \%$ & $18 \%$ & Rp5.500.000 & Rp6.500.000 & Rp8.500.000 \\
\hline 4 & $\begin{array}{l}\text { Beth Kasegaran } \\
\text { Theresia Senior } \\
\text { Living \& Resort }\end{array}$ & 72,8 & $73 \%$ & $16 \%$ & Rp14.610.750 & Rp18.442.250 & Rp27.769.500 \\
\hline 5 & $\begin{array}{l}\text { Rukun Senior } \\
\text { Living }\end{array}$ & 79,6 & $80 \%$ & $17 \%$ & - & Rp18.900.000 & Rp32.400.000 \\
\hline 6 & $\begin{array}{l}\text { Senior Living } \\
\text { D'Khayangan }\end{array}$ & 81,5 & $82 \%$ & $17 \%$ & Rp5.292.205 & Rp10.317.354 & Rp17.909.771 \\
\hline
\end{tabular}

Sumber: Penulis, 2019

Dari hasil market positioning menggunakan metode forecast pada excel untuk menentukan harga sewa, di bagi menjadi 3 macam kamar apartemen yang disesuaikan dengan kelas ekonomi masyarakat yaitu kelas lower, middle dan upper. Harga yang ditetapkan untuk kelas lower adalah $\mathrm{Rp} 5.300 .000,-$, untuk kelas middle adalah $\mathrm{Rp} 10.300 .000,-$, dan kelas upper adalah $\mathrm{Rp}$ 17.900.000,-- 
Tabel 3. Hasil Perhitungan Market Absorption

\begin{tabular}{ccl}
\hline Indikator & Jumlah & \multicolumn{1}{c}{ Keterangan } \\
\hline Total Demand & 240.651 & $\begin{array}{l}\text { (Total demand lansia 60 tahun keatas yang } \\
\text { berdomisili di Jabodetabek } \mathbf{x} \text { Persentase 20\% } \\
\text { penghasilan lansia teratas) } \mathbf{x} \text { Persentase } \\
\text { demand perminatan lansia terhadap senior } \\
\text { housing dari hasil kuesioner }\end{array}$ \\
\hline Jumlah Proyeksi & 270.604 & $\begin{array}{l}\text { Proyeksi jumlah lansia di Jabodetabek dalam 10 } \\
\text { tahun (tahun 2029) }\end{array}$ \\
\hline Total Unit Demand & 347 & $\begin{array}{l}\text { Total jumlah unit kamar senior housing di lokasi } \\
\text { kompetitor }\end{array}$ \\
\hline Demand Pertumbuhan Alami & $104 \%$ & $\begin{array}{l}\text { Persentase pertumbuhan demand selama } \\
\text { proyeksi 10 tahun }\end{array}$ \\
\hline Potensial Unit Demand & 360 & $\begin{array}{l}\text { Jumlah unit kamar yang berpotensi x } \\
\text { Persentase demand pertumbuhan alami }\end{array}$ \\
\hline Market Share & $17 \%$ & Hasil perhitungan dari market positioning \\
\hline Total Unit yang Dapat Diserap & 61 & Potensial Demand $\mathbf{x}$ Market Share \\
\hline
\end{tabular}

Sumber: Penulis, 2019

Dari hasil perhitungan market absorption tabel diatas, total unit yang dapat diserap adalah total 61 unit. Maka pembangunan minimal menyediakan 61 unit dan dalam rencana akan membangun unit berdasarkan kelas yaitu lower, middle, upper (A), upper (B).

Tabel 4. Kesimpulan

\begin{tabular}{ccl}
\hline No & Analisis & \multicolumn{1}{c}{ Kesimpulan } \\
\hline 1 & Analisis & Trend senior housing di Indonesia yang dilihat melalui senior \\
& Benchmarking & housing yang di jadikan benchmark adalah bahwa peminat senior \\
& housing di Indonesia merupakan lansia yang telah ditinggal oleh \\
& pasangannya, tidak menikah, ataupun ingin mandiri. Selain \\
& mengetahui karakter lansia, sumber penghasilan lansia yang tinggal \\
& merupakan lansia yang memiliki gaji pensiunan yang cukup maupun \\
& pemberian anak \& simpanan bank. Lansia yang tinggal tidak terlalu \\
& mementingkan jenis fasilitas rutin maupun hiburan yang ada, \\
& selama lansia masih mendapatkan fasilitas yang sesuai dengan harga \\
& sewa yang dibayarkan. Lansia tidak mementingkan lokasi yang jauh \\
& dari rumah anak/asal karena lansia tidak membutuhkan mobil untuk \\
& dikendarai ke luar kawasan dan fasilitas yang tersedia sudah \\
& mencukupi kebutuhannya. \\
\hline Analisis Pasar & Produk yang tergolong baru di Indonesia, senior housing, tidak \\
& memiliki supply yang banyak yang dikarekakan demand yang ada \\
& juga tidak signifikan. Namun dari hasil analisis sebelumnya, segmen \\
& pasar senior housing kelas atas di Jabodetabek adalah sebesar \\
& 240.651 jiwa. Dengan jumlah market absorption sebesar 61 unit dan \\
& market positioning dengan membagi 4 tipe kamar berdasarkan luas \\
& dimensi dari range harga Rp 5.000.000 - Rp 21.000.000 per unit.
\end{tabular}

Sumber: Penulis, 2019

Dari ke 2 analisis yang telah dilakukan, dapat disimpulkan bahwa Senior Living D'Khayangan Jababeka, Cikarang memiliki segmentasi pasar yang unik. Segmentasi pasar yang ada

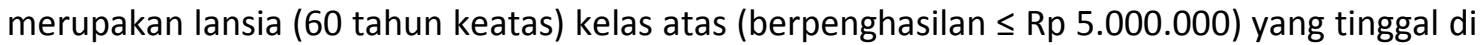
Jabodetabek dan masih mandiri. Namun minat terhadap senior housing bergantung kepada 
kondisi keluarga yang sudah terpisah dengan anak maupun telah ditinggalkan pasangan dan tidak memiliki kegiatan harian. Jadi dalam ketertarikan lansia terhadap senior housing bukan karena kondisi ekonomi namun dipicu oleh faktor kondisi keluarga, fisik dan tingkat kesibukan lansia.

Untuk mencapai tujuan yang diharapkan seperti pada analisis yang telah dilakukan, berikut adalah rekomendasi dari beberapa aspek untuk meningkatkan occupancy rate agar dapat mencapai keberhasilan seperti yang di rencanakan dalam analisis finansial:

a. Lokasi dari Senior Living D'Khayangan Jababeka Cikarang ini dapat menjadi tempat strategis karena terdapat dalam township Jababeka yang memiliki banyak daya tarik terutama dalam 5-10 tahun kedepan dengan konsep pengembangan kota baru. Selain masyarakat lokal, masyarakat kaum expatriat menjadi sasaran utama dari senior living ini namun dalam kenyataannya, hanya beberapa expatriat yang lebih memilih untuk tinggal di apartemen. Untuk mengatasi hal tersebut harus dibuat tipe kamar yang tidak hanya di khususkan untuk kalangan menengah atas, namun juga untuk menengah kebawah walaupun dengan jumlah yang lebih sedikit dibandingkan dengan unit middle-up.

b. Masalah budaya Indonesia yang menganggap senior housing adalah "tempat pembuangan orang tua" harus diubah melalui branding dan cara marketing melakukan promosi.

c. Fasilitas yang ada dalam senior living menjadi ukuran harga sewa yang ditetapkan namun dengan demikian, dapat menjadi halangan karena harga yang terlalu tinggi bagi calon penghuni.

d. Fasilitas sekitar dapat dimanfaatkan bagi promosi, seperti kedekatan dengan pemakaman kelas atas (San Diego Hills, Al Azhar Memorial Garden, dll) dan aksesnya dapat menjadi daya tarik bagi lansia yang menjadi calon penghuni.

\section{REFERENSI}

Benbow, W.A. (2014) Best Practice Design Guidlines: Design Complex care. United States: Deparment Veteran Affairs.

Brunswick. (2010). Design Standards for Nursing Homes. Inggris: Department of Supply and Service.

Cooper M., Clare dan Carolyn F. (2001). People Places: Design Guidelines for Urban Open Space. 2nd edition. New York: Van Nostrand Reinhold.

Kandel, J. dan Adamec, C. (2013).The Encyclopedia of Senior Health and Well-Being. London: Eurospan.

Maryam, R.S. Ekasari dan Mia F. R. (2008). Mengenal Usia Lanjut dan Perawatannya. Indonesia. Jakarta: Salemba Medika.

Pearce, B. W. (2007). Senior Living Communities: Operations Management and Marketing for Assisted Living, Congregate, and Continuing Care Retirement Communities. Baltimore: Johns Hopkins University Press.

Manning, J. (Dec 21 1998). Milawaukee Journal Sentinel: Aging Population's Needs Create Senior Housing Boom. 68-69.

Koopmanschap, M.A. dan Van Exel, J.N.A. \& Berg, Bernard \& Brouwer, Werner. (2008). An overview of methods for evaluating informal care in economic health studies. PharmacoEconomics - Italian Research Articles. 10. 99-111.

Undang-Undang Republik Indonesia No. 4 Pasal 1 (1965). Pemberian Bantuan Penghidupan Orang Jompo. Jakarta: Sekretaris Negara Republik Indonesia.

Undang-Undang Republik Indonesia No. 13 (1998). Kesejahteraan Lanjut Usia. Jakarta: Sekretaris Negara Republik Indonesia.

The Westminster Municipal. (2013). City of Westminster, Colorado: Senior Housing Design Standards, diunduh 28 Maret 2019, https://www.cityofwestminster.us/Portals/1/Documents/Government\%20- 
\%20Documents/Departments/Community\%20Development/SeniorHousing.pdf

Marchand, B. (2014). Architecture for the Elderly. Swiss: Press Polytechniques, diunduh 3 April 2019, https://medicalxpress.com/pdf308907660.pdf

Maxfield Reaserch inc. (2010). Market Feasibility Study for an Independernt Senior Rental Development in Lexington, Minnesota, diunduh 6 April 2019,

https://www.anokacounty.us/DocumentCenter/View/491/Market-Feasibility-Study-forSenior-Rental-Development-in-Lexington-PDF 
